\title{
ANALISIS HADIS-HADIS TENTANG TASTWIB
}

\author{
Dame Siregar \\ Lecturer of Syariah and Law Sciences Faculty at IAIN Padangsidimpuan \\ Jl. T. Rizal Nurdin Km. 4,5 Sihitang Padangsidimpuan 22733 \\ E-mail: dame.iain@gmail.com
}

\begin{abstract}
Abstrac
Tatswib is the saying of asshalatu khairumminannaum. It is bid'ah to say it in adzan for the Zuhur and 'Asr praying, or even in Maghrib and Isha. It is also bid'ah for the second adzan on Subuh (morning prayer), but it is not for the first adzan, one hour before entering the time. Bid'ah is also for adding or substracting words from Alqur'an and hadist. Adding the words of tasbih, tahmid, and takbir from 33 times, or even adding the sayings before or between them is also bid'ah. Another explanation about additional words to saying salawat to the Prophet Muhammad or giving the word sayyidina to shalawat also includes as bid'ah. There are also the changes to the real words of $d o^{\prime} a$ between the singular meanings to the plural one, or in the other hand. Finally, it is better not to change the sayings of redaction from Alqur'an and Hadist, or make it silently likes in prayer in order not to disturb others.
\end{abstract}

Keywords: Worship, dalil, Alqur'an, sunnah, and bid'ah

\begin{abstract}
Abstrak
Tastwib adalah bacaan الصلاة خير من النوم bid'ah membacanya pada adzan solat Zuhur dan 'Asar,tentu demikian pada solat Magrib dan Isya' dan solat subuh pada adzan kedua. Pada adzan pertama sebelum masuk waktu subuh disepakati satu jam sebelum masuk waktu subuh. Analisisnya terhadap ibadah lain adalah menambahi atau mengurangi bacaan yang sudah ada dalam Alquran dan hadis. Menambahi tasbih, tahmid dan takbir dari 33 kali, demikian juga nenambahi bacaan sebelum membaca tasbih, antara tasbih dengan tahmid, antara tahmid dengan takbir. Menambahi bacaan tasyahud awal dengan solawat kepada Nabi. Solawatnyapun hanya diawal saja tidak sempurna sesuai dengan solawat berdasarkan hadis Rosul. Kemudian juga menambahi kata wيدنا pada bacaan solawat. Dalam berdoa berjamaah, dirobahlah ayat atau hadis dari yang mufrod atau tunggal menjadi jama' karena kondisi doa bersama. Namun sebaliknya tidak berani merubah ayat atau hadis yang jama' semjla merubahnya menjadi mufrod atau tunggal saat doa sendirian. Sebaiknya jangan robah redaksi ayat atau hadis maka berdoalah dengan masing-masing berbisik agar tidak mengganggu orang lain seperti dalam solat
\end{abstract}

Kata kunci: Ibadah, dalil, Alquran dan Sunnah, dan bid'ah 


\section{PENDAHULUAN}

Ibadah saleh merupakan amalan yang baik dan sempurna dalam rangka taqorrub kepada Alloh Subhanahu wa ta'ala.Taqorrub kepada-Nya suatu kebutuhan yang utama dalam menjalani hidup di dunia ini sebagai bekal dalam kehidupan di akhirat. Manusia tidak sanggup membuat metode yang baik dan sempurna dalam hal hablum minalloh makanya Alloh Subhanahu wa ta'ala mengutus Rosul-Nya serta diturunkan kepadanya Kitab Alquran dan hadis sebagai pedoman. Alquran belum bisa dipahami umat secara mendalam dan benar, makanya Rosulullah sollallohu 'alaihi wa sallam diberikan hak dalam membuat hukum untuk menjelaskan Alquran. Makanya Alquran dan hadis tidak bisa dipisahkan. Alquran sendiri yang menjelaskan bahwa Alquran dan sunnah dua pedoman saling menjelaskan. Firman Alloh Subhanahu wa ta'ala sebagai berikut:

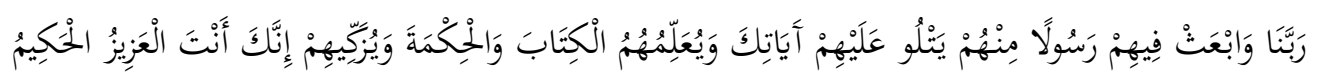

Artinya: Ya Tuhan kami, utuslah untuk mereka sesorang Rasul dari kalangan mereka, yang akan membacakan kepada mereka ayat-ayat Engkau, dan mengajarkan kepada mereka Al Kitab (Al Quran) dan Al-Hikmah (As-Sunnah) serta mensucikan mereka. Sesungguhnya Engkaulah yang Maha Kuasa lagi Maha Bijaksana. ${ }^{1}$

Ayat ini menjelaskan bahwa Alquran setara dengan sunnah, berarti kata al-hikmah dalam Alquran maksudnya adalah sunnah atau hadis, selanjutnya kata hadis ada yang artinya adalah Alquran dalilnya sebagai berikut:

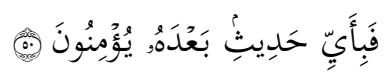

Artinya: Maka kepada perkataan apakah selain Al Quran ini mereka akan beriman ${ }^{2}$

\section{PEMBAHASAN}

Kata tastwib maksudnya adalah bacaan الصَّلَاة خَيْر مِنْ النَّوْم pada adzan solat pertama sebelum masuk waktu solat subuh untuk membangunkan orang sedang tidur, agar umat Islam solat lail dan witir atau solat sunnah mutlaq setelah witir, makanya waktu mengumandangkan adzan pertamanya disepakati, ditempat itu pukul berapa dikumandangkan, agar paham seluruh umat yang dapat mendengarnya bahwa adzan pertama belum masuk waktu subuh tetapi membangunkan orang untuk solat sunnah lail witir dan mutlaq. Dalilnya sebagai berikut:

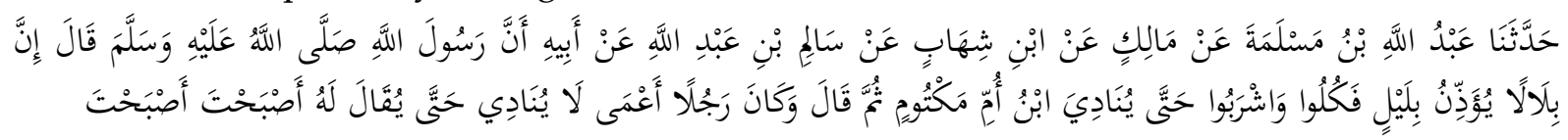

\footnotetext{
${ }^{1}$ Q.S. al-Baqoroh, 2:129

${ }^{2}$ Q.S. al-Mursalat, 77:50
} 
Artinya: (BUKHARI - 582) : Telah menceritakan kepada kami 'Abdullah bin Maslamah dari Malik dari Ibnu Syihab dari Salim bin 'Abdullah dari Bapaknya, bahwa Rasulullah shallallahu 'alaihi wasallam bersabda: "Sesungguhnya Bilal mengumandangkan adzan saat masih malam, maka makan dan minumlah sampai kalian mendengar adzan Ibnu Ummi Maktum." Perawi berkata, "Ibnu UmmuiMaktum adalah seorang sahabat yang buta, ia tidak akan mengumandangkan adzan (shubuh) hingga ada orang yang mengatakan kepadanya, 'Sudah shubuh, sudah shubuh'."3

Di kota Madinah al-Munawwaroh, satu jam sebelum masuk waktu subuh dikumandangkan adzan pertama, waktu ini boleh dipedomani ditempat lain, karena ahlul Madinah al-Munawwaroh tentu ada yang mewarisi amalan Nabi samapai sekarang, demikian juga di Madinah al-Munawwaroh adzan pertama Jumu'ah satu jam sebelum masuk waktu jumu'ah

Jika ada umat Islam ada adzan yang dibacakan kata tastwib pada solat zuhur dan 'asar adalah bid'ah, dalilnya sebgai berikut:

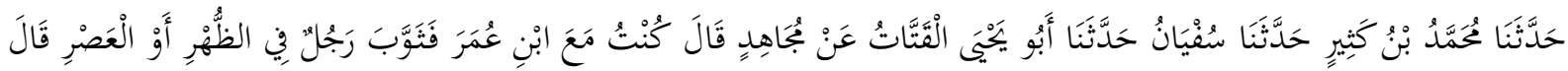

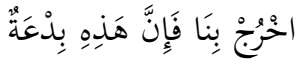

Artinya: (ABUDAUD - 453) : Telah menceritakan kepada kami Muhammad bin Katsir telah menceritakan kepada kami Sufyan telah menceritakan kepada kami Abu Yahya Al-Qattat dari Mujahid dia berkata; Saya pernah bersama Ibnu Umar, lalu ada seseorang yang mengumandangkan adzan dengan menambah tatswib (kalimat Ashsholatu khoirun minannaum) pada waktu Zhuhur atau Ashar, maka Ibnu Umar berkata; Keluarlah dengan kami, sesungguhnya ini perbuatan bid'ah ${ }^{4}$.

Hadis ini kualitas sanadnya adalah hasan menurut hasil takhrij Muhammad Nasiruddin al-Albani datanya sebagai berikut:

504 - ( حسن ) عن مجاهد قال كنت مع ابن عمر فثوب رجل في الظهر أو العصر قال اخرج بنا فإن هذه بدعة * ( حسن )5

Alasan penulis mencantumkan kualitas sanad hadis, adalah menginformasikan kepada pembaca, agar tidak ragu lagi hadis tersebut. Kemudian sekaligus mencontohkan agar setiap hadis wajib diketahui kualitas sanadnya. Karena ilmu hadis bukan hanya sekedar dipelajari dan ditelusuri, namun sangat perlu untuk dipublikasikan melalui karya ilmiah, skripsi, thesis, disertasi dan penelitian hadis

Sepakat semua orang membawa kitab cetakan, akan menemui hambatan untuk membawanya ke tempat pengajian, kuliah, sekolah ke kantor dan tempat lainnya. Namun dengan adanya aplikasi al-maktabah asy-Syamilah dan kitab 9 Imam hadis dan aplikasi

\footnotetext{
${ }^{3}$ Lidwa Pusaka i-Software - Kitab 9 Imam Hadist, Sumber : Bukhari Kitab : Adzan Bab : Adzannya orang yang buta jika diberitahu masuknya waktu shalat No. Hadist : 582, http://localhost:5000/perawi_open.php?imam=bukhari\&nohdt=582

${ }^{4}$ Lidwa Pusaka i-Software - Kitab 9 Imam Hadist, Sumber : Abu Daud Kitab : Shalat Bab : Tatswib (ucapan Laa Haula Walaa Quwwata Illa Billahi) No. Hadist : 453, Lidwa Pusaka i-Software: www.lidwapustaka.com

5 5كتاب : إرواء الغليل في تخريج أحاديث منار السبيل المؤلف : مُحَّة ناصر الدين الألباني الناشر : المكتب الإسلامي - بيروت الطبعة : الثانية - 1405 - 145 -

1985 عدد الأجزاء : 8 ج1 ص 254
} 
lainnya maka akan memudahkan bagi semua umat Islam mengkaji dari segi sumbernya. Maka sepertinya wajib memilikinya dengan tujuan memasyarakatkannya

\section{Penjelasan Kitab Syarah Hadis}

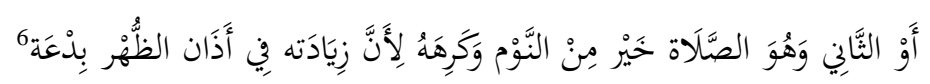

Masalah yang kedua adalah bacaan adzan الصنَلَة خَبْر مِنْ النَّوْم adalah bid'ah, karena sangat dibencii disebabkan menambahinya pada adzan zuhur

$$
\text { قال البيهقى لم تثبت هذه اللفظة عن النبي }
$$

Al-Baihaqi berkata: Lafdaz الصَّكَاة خَيْر مِنْ النَّوْم yang disandarkan kepada Nabi sollallohu 'alahi wa sallam, maka kami membenciinya karena menambahi lafadz adzan wallohu a'lam. Maksudnya selain adzan solat pertama subuh

Penjelasan

1. Hadis ini kualitas sanadnya hasan, berarti bisa menjadi dalil menurut ilmu hadis, karena perbedaan hadis hasan dengan hadis sohih hanya kurangnya kedobitan sebagian di antara sanad hadisnya bukan pada matan hadisnya

2. Kata tastwib bid'ah membacanya pada adzan solat Zuhur dan 'Asar, tentu demikian pada solat Magrib dan Isya' dan solat subuh pada adzan kedua, yang ada dalilnya adzan pertama sebelum masuk waktu subuh. Dalil at-tastwib pada adzan pertama adalah sebagai berikut:

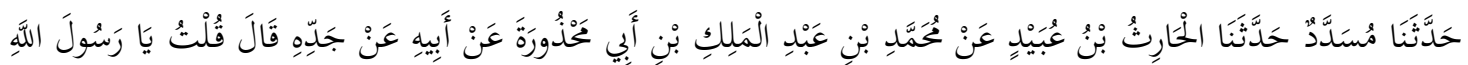

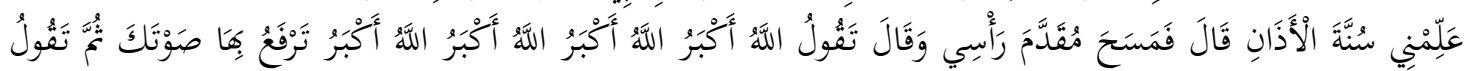

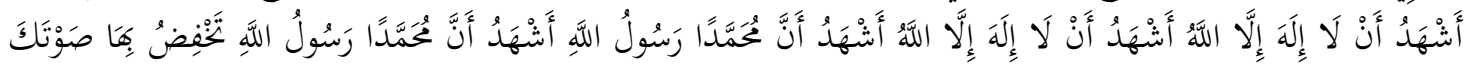

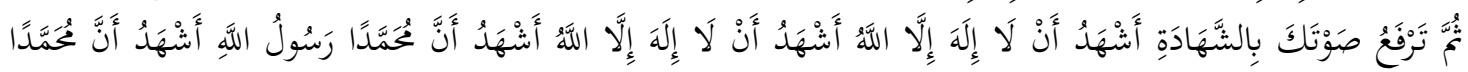

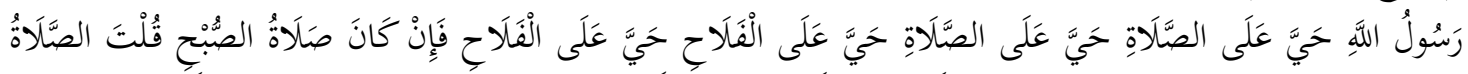

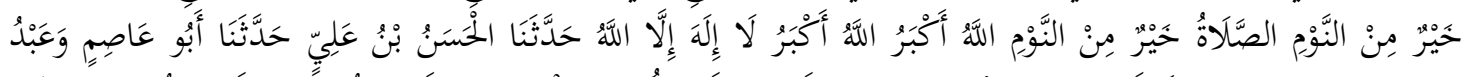

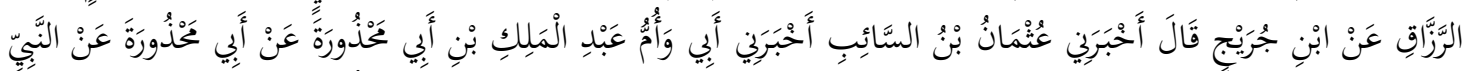

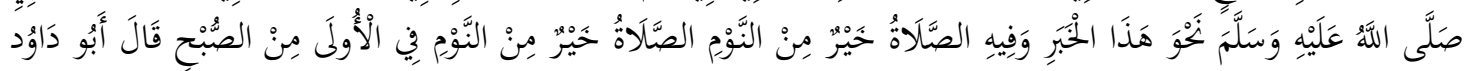

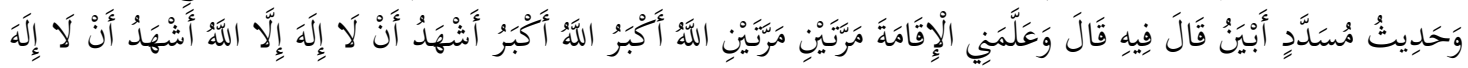

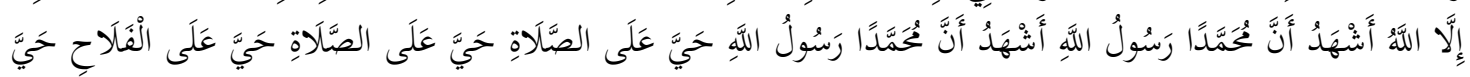

6مصدر الكتاب : موقع الإسلام http://www.al-islam.com [ الكتاب مشكول عون المعبود -ومرقم آليا غير موافق للمطبوع ]ج 2

$$
\text { الكتاب : الخموع مصدر الكتاب : موقع يعسوب ج } 3 \text { ص } 98
$$




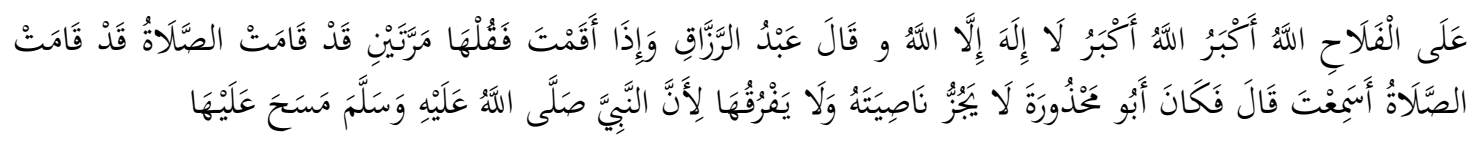

Artinya: (ABUDAUD - 422) : Telah menceritakan kepada kami Musaddad telah menceritakan kepada kami Al-Harits bin Ubaid dari Muhammad bin Abdul Malik bin Abu Mahzhurah dari Ayahnya dari Kakeknya dia berkata; Saya berkata; Wahai Rasulullah, ajarkanlah kepadaku sunnah (tata cara) adzan. Katanya; Maka beliau mengusap bagian depan kepalaku dan bersabda: "Kamu ucapkan; Allahu akbar Allahu akbar, Allaahu akbar, Allahu akbar (Allah Maha Besar Allah Maha Besar, Allah Maha Besar Allah Maha Besar), kamu angkat suaramu ketika mengucapkannya, kemudian kamu ucapkan, Asyhadu an laa ilaaha illallaah Asyhadu an laa ilaaha illallah (Aku bersaksi bahwasanya tidak ada tuhan yang berhak disembah selain Allah, aku bersaksi bahwasanya tidak ada tuhan yang berhak disembah selain Allah), Asyhadu anna Muhammadar Rasuulullah, Asyhadu anna muhammadar Rasuulullah (Aku bersaksi bahwa Muhammad adalah utusan Allah, Aku bersaksi bahwa Muhammad adalah utusan Allah) Kamu rendahkan suaramu tatkala mengucapkannya, setelah itu kamu angkat suaramu ketika mengucapkan syahadat, Asyhadu an laa ilaaha illallah, asyhadu an laa ilaaha illallah (Aku bersaksi bahwasanya tidak ada tuhan yang berhak disembah selain Allah, Aku bersaksi bahwasanya tidak ada tuhan yang berhak disembah selain Allah), Asyhadu anna Muhammadar rasulullah, asyhadu anna Muhammadar Rasulullah (Aku bersaksi bahwasanya Muhammad adalah utusan Allah, Aku bersaksi bahwasanya Muhammad adalah utusan Allah) Hayya 'Alash shalaah, hayya 'alas shalaah (Mari mendirikan shalat, mari mendirikan shalat) Hayya 'Alal falaah, hayya 'alal falaah (Mari menuju kemenangan, Mari menuju kemenangan). Kalau adzan untuk shalat Subuh, ucapkanlah, Ash shalaatu khairun minan nauum, Ash shalaatu khairun minan nauum (shalat itu lebih baik daripada tidur, shalat itu lebih baik daripada tidur), Allaahu akbar, Allaahu akbar (Allah Maha Besar, Allah Maha Besar) Laa ilaaha illallah (Tiada tuhan yang berhak disembah selain Allah)." Telah menceritakan kepada kami Al-Hasan bin Ali telah menceritakan kepada kami Abu 'Ashim dan Abdur Razzaq dari Ibnu Juraij dia berkata; Telah mengabarkan kepadaku Utsman bin As-Sa`ib Telah mengabarkan kepadaku Ayahku dan Ummu Abdil Malik bin Abi Mahzhurah dari Abu Mahzhurah dari Nabi shallallahu 'alaihi wasallam seperti lafazh hadits ini, dan di dalamnya disebutkan ucapan kalimat; Ash shalaatu khairun minan nauum, Ash shalaatu khairun minan nauum (shalat itu lebih baik daripada tidur, shalat itu lebih baik daripada tidur) pada Shubuh yang pertama. Abu Dawud berkata; Hadits Musaddad lebih jelas. Dia menyebutkan padanya; dia berkata; Beliau mengajarkanku tata cara iqamat dengan dua kali dua kali; Allahu Akbar Allahu Akbar, Asyhadu anlaa ilaaha illallah, Asyhadu anlaa ilaaha illallah, Asyhadu anna Muhammadar rasulullah, Asyhadu anna Muhammadar rasulullah, Hayya 'alash Shalah, Hayya 'alash Shalah, Hayya 'alal Falah, Hayya 'alal Falah, Allahu Akbar Allahu Akbar, Laa ilaaha illallah. Dan Abdur Razzaq menyebutkan; Apabila kamu mengumandangkan iqamat, maka ucapkanlah dua kali; yakni Qad qaamatish Shalah, Qad qaamatish Shalah, apakah kamu telah mendengarnya? Katanya; Maka Abu Mahdzurah tidak pernah mencukur ubun 
ubunnya, dan tidak pernah membelahnya, karena Nabi shallallahu 'alaihi wasallam pernah mengusapnya. ${ }^{8}$

Hadis ini kualitas sanadnya adalah hasan menurut hasil takhrij Muhammad Nasiruddin al-Albani datanya sebagai berikut:

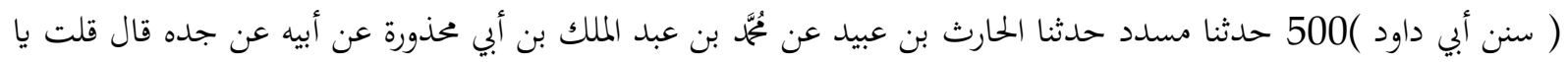

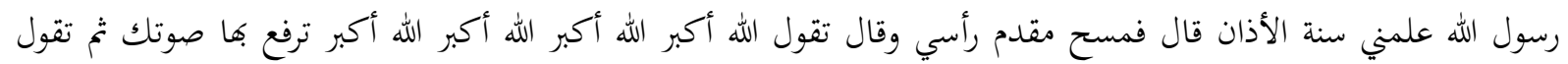

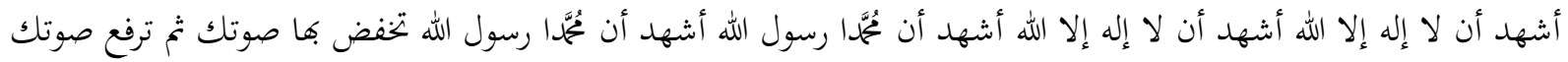

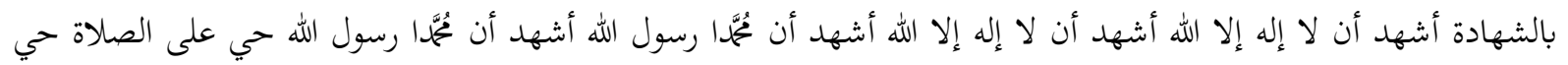

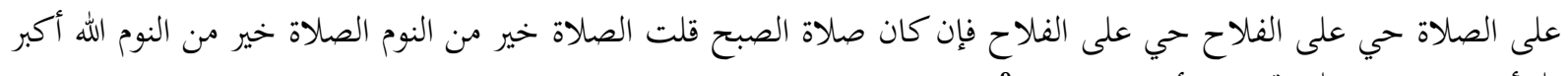

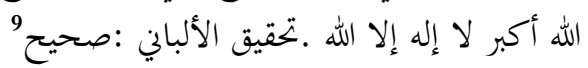

Penguat

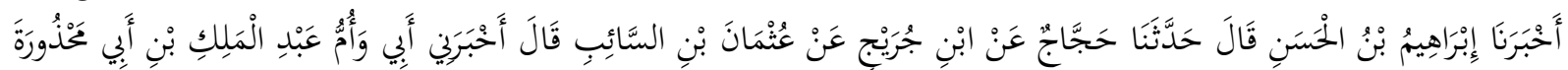

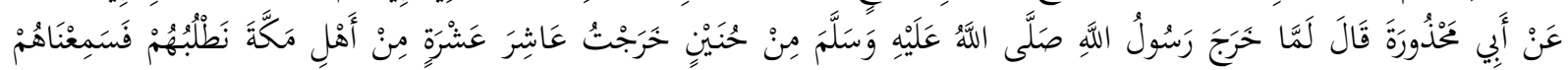

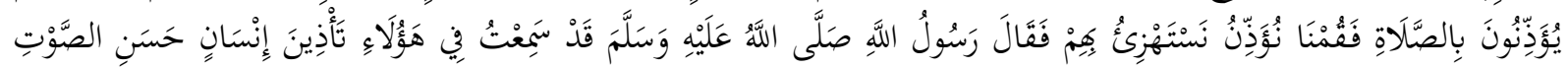

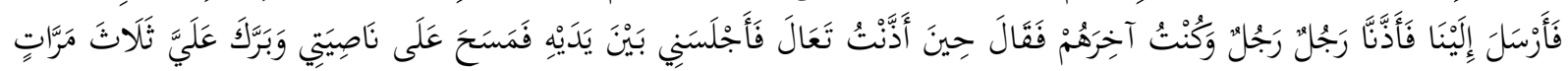

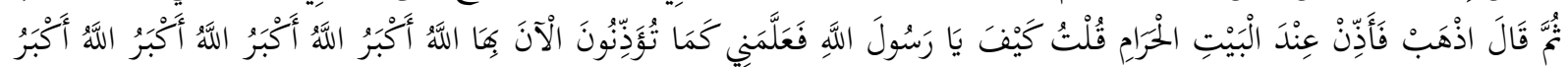

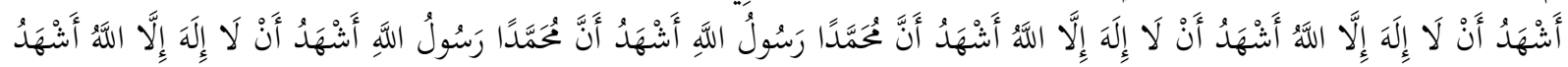

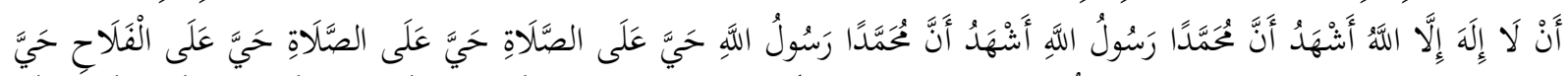

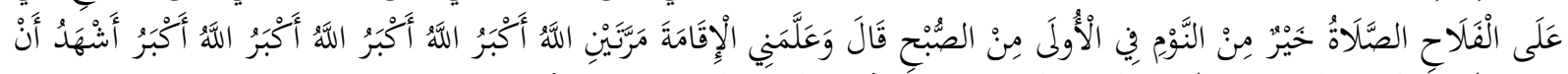

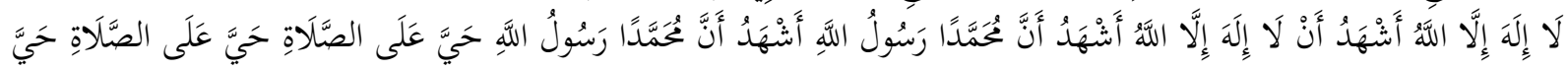

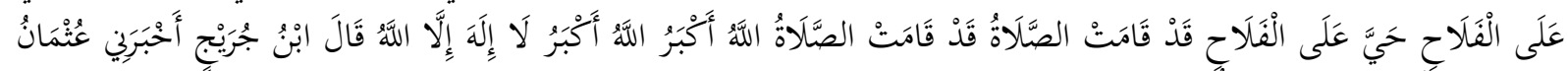

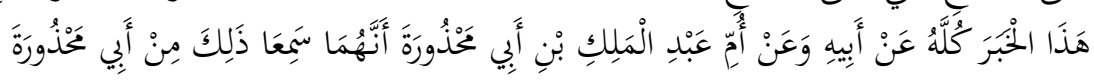

Artinya: (NASAI - 629) : Telah mengabarkan kepada kami Ibrahim bin Al-Hasan dia berkata; telah menceritakan kepada kami Hajjaj dari Ibnu Juraij dari 'Utsman bin As-Saib dia berkata; bapakku dan Ummu 'Abdul Malik bin Abu Mahdzurah telah mengabarkan kepadaku dari Abu Mahdzurah dia berkata; "Tatkala Rasulullah Shallallahu'alaihi wasallam keluar dari Hunain, aku orang yang kesepuluh dari sepuluh orang Quraisy yang pergi mencari mereka (Rasulullah Shallallahu'alaihi wasallam dan para sahabat). Kami mendengar mereka mengumandangkan adzan untuk shalat, maka kami mulai ikut adzan sebagai ejekan kepada mereka. Oleh karena itu Rasulullah Shallallahu'alaihi wasallam bersabda: 'Aku mendengar seseorang yang merdu suaranya di antara mereka mengumandangkan adzan'. Beliau Shallallahu'alaihi wasallam mengutus seseorang kepada kami, lalu kamipun mengumandangkan adzan satu persatu dan aku orang yang terakhir. Ketika mendengarku mengumandangkan adzan beliau Shallallahu'alaihi wasallam berkata, 'Kemari'. Beliau mempersilakanku duduk di depannya dan mengusap ujung rambutku, serta mendoakan keberkahan untukku -sampai tiga kali- kemudian berkata, 'Pergilah dan kumandangkan

${ }^{8}$ Lidwa Pusaka i-Software - Kitab 9 Imam Hadist, Sumber : Abu Daud Kitab : Shalat Bab : Cara adzan No. Hadist : 422, http://localhost:5000/perawi_open.php?imam=abudaud\&nohdt=422 , Lidwa Pusaka iSoftware: www.lidwapustaka.com

9 الكتاب : صحيح وضعيف سنن أبي داود المؤلف : محمَّ ناصر الدين الألباني مصدر الكتاب : برنامج منظومة التحقيقات الحديثية - الجماني - من إنتاج مركز

نور الإسلام لأبحاث القرآن والسنة بالإسكندرية ج1 ص ص ص 520 
adzan di Masjidil Haram". Aku berkata, 'Bagaimana caranya wahai Rasulullah Shallallahu'alaihiwasallam? ' Lalu beliau mengajariku sebagaimana yang kalian ucapkan saat adzan sekarang: "allaahu akbar allaahu akbar, allaahu akbar allaahu akbar (Allah Maha Besar, Allah Maha Besar, Allah Maha Besar, Allah Maha Besar). asyhadu an laa ilaaha illallaah, asyhadu an laa ilaaha illallaah, (Aku bersaksi bahwa tidak ada tuhan yang berhak disembah kecuali Allah. Aku bersaksi bahwa tidak ada tuhan yang berhak disembah kecuali Allah) asyhadu anna muhammadar rasuulullah, asyhadu anna muhammadar rasuulullah (Aku juga bersaksi bahwa Muhammad adalah utusan Allah, aku juga bersaksi bahwa Muhammad adalah utusan Allah). asyhadu an laa ilaaha illallaah, asyhadu an laa ilaaha illallaah, (Aku bersaksi bahwa tidak ada tuhan yang berhak disembah kecuali Allah. Aku bersaksi bahwa tidak ada tuhan yang berhak disembah kecuali Allah) asyhadu anna muhammadar rasuulullah, asyhadu anna muhammadar rasuulullah (Aku juga bersaksi bahwa Muhammad adalah utusan Allah, aku juga bersaksi bahwa Muhammad adalah utusan Allah). hayya 'alash shalaah, hayya 'alash shalaah (Mari mengerjakan shalat, mari mengerjakan shalat), hayya 'alal falaah, hayya 'alal falaah, (Mari mencapai kebahagiaan, mari mencapai kebahagiaan), ash shalaatu khairumminannaum (Shalat itu lebih baik daripada tidur) -pada adzan pertama saat shalat Subuh-." dia berkata; "Beliau mengajari iqamah dua kali: allaahu akbar allaahu akbar (Allah Maha Besar, Allah Maha Besar) asyhadu an laa ilaaha illallaah, asyhadu an laa ilaaha illallaah, (Aku bersaksi bahwa tidak ada tuhan yang berhak disembah kecuali Allah. Aku bersaksi bahwa tidak ada tuhan yang berhak disembah kecuali Allah). asyhadu anna muhammadar rasuulullah, asyhadu anna muhammadar rasuulullah (Aku juga bersaksi bahwa Muhammad adalah utusan Allah, aku juga bersaksi bahwa Muhammad adalah utusan Allah). hayya 'alash shalaah, hayya 'alash shalaah (Mari mengerjakan shalat, mari mengerjakan shalat), hayya 'alal falaah, hayya 'alal falaah, (Mari mencapai kebahagiaan, mari mencapai kebahagiaan). qad qaamatish shalaah, qad qaamatish shalaah (Shalat telah siap ditegakkan, shalat telah siap ditegakkan). allaahu akbar allaahu akbar (Allah Maha Besar Allah Maha Besar), laa ilaaha illallaah, (Tidak ada tuhan yang berhak disembah kecuali Allah)."10

\section{PENGUAT}

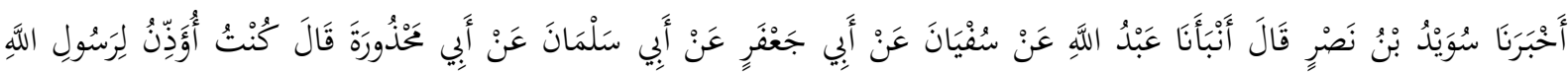

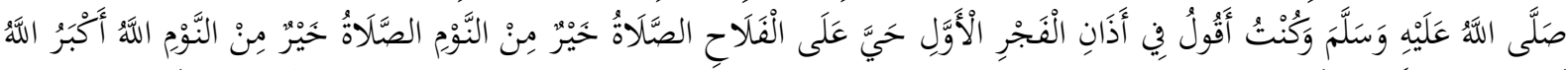

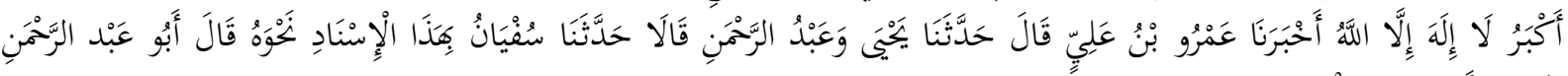

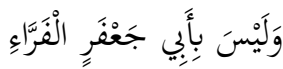

Artinya: (NASAI - 643) : Telah mengabarkan kepada kami Suwaid bin Nashr dia berkata; telah memberitakan kepada kami 'Abdullah dari Sufyan dari Abu Ja'far dari Abu Salman dari Abu Mahdzurah dia berkata; "Aku pernah adzan untuk Rasulullah Shallallahu'alaihi wasallam dan aku mengucapkan (kalimat) pada adzan Fajar pertama: HAYYA 'ALAL FALAAH (mari menggapai kebahagiaan) ASH SHALAATU KHAIRUM MINANNAUM (shalat lebih baik dari pada tidur), ASHSHALATU KHAIRUM MINANNAUM (shalat lebih baik dari pada tidur). ALLAAHU AKBAR (Allah Maha Besar), ALLAAHU AKBAR (Allah Maha Besar), LAA ILAAHA ILLALLAAH (Tidak ada Tuhan yang berhak disembah

${ }^{10}$ Lidwa Pusaka i-Software - Kitab 9 Imam Hadist, Sumber : Nasa'I Kitab : Adzan Bab : Adzan ketika safar No. Hadist : 629, http://localhost:5000/perawi_open.php?imam=nasai\&nohdt=629, www.lidwapusaka.com 
selain Allah)." Telah mengkabarkan kepada kami Amr bin Ali dia berkata; Telah menceritkan kepada kami Yahya dan Abdurrahman mereka berkata; Telah menceritakan kepada kami Sufyan dengan sanad yang serupa. Abu Abdurrahman berkata; "Tapi bukan dari Abu Ja'far Al Farra."11

\section{Analisis}

1. Bacaan tatswib di luar bacaan adzan solat subuh adalah bid'ah, tentu perlu dipahami secara mendalam, dalam hal menambahi atau mengurangi bacaan dalam solat karena menambahi atau mengurangi salah, menambahi atau mnegurangi yang tidak diperintahkan tentu bid'ah

2. Menambahi bacaan solat atau meninggalkan bacaan yang sudah ada ketentuannya tentu bid'ah, seperti bacaan doa qunut witir dalam hadis, namun masih ada umat dibacanya pada solat subuh termasuk hadis yang mengandung bid'ah dalilnya:

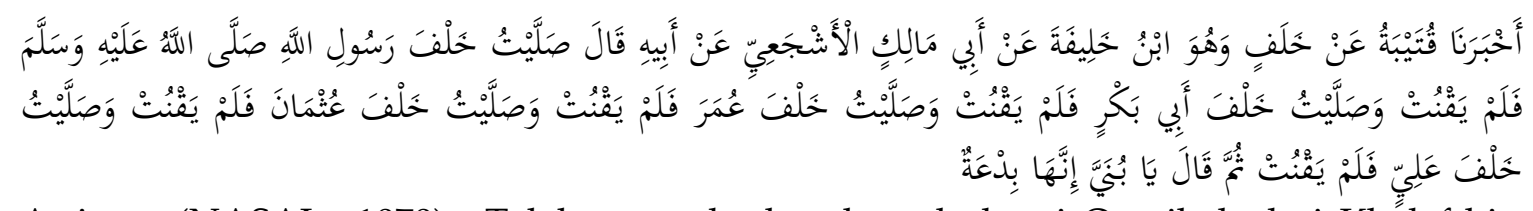

Artinya: (NASAI - 1070) : Telah mengabarkan kepada kami Qutaibah dari Khălaf bin Khalifah dari Abu Malik Al Asyja'i dari bapaknya dia berkata; "Aku pernah shalat di belakang Rasulullah ShallAllohu'alaihi wasallam, dan beliau tidak qunut. Aku juga pernah shalat di belakang Abu Bakar, dan ia tidak qunut. Aku pernah shalat di belakang Umar, dan beliau tidak qunut. Aku pernah shalat di belakang Utsman, dan beliau tidak qunut. Aku juga pernah shalat di belakang Ali, dan beliau juga tidak qunut. Kemudian ia berkata, 'Wahai anakku, itu adalah bid'ah ${ }^{12 "}$.

Hadis ini kualitas sanadnya adalah sohih menurut hasil takhrij Muhammad Nasiruddin al-Albani sebagaimana datanya sebagai berikut:

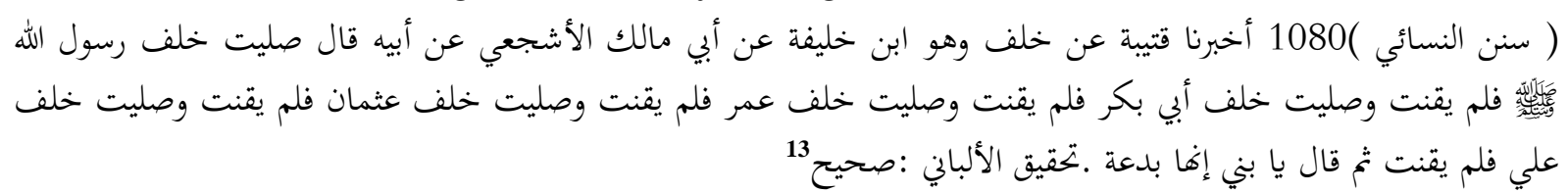

Hadis bahwa Nabi selalu berqunut subuh sampai akhir hayatnya bertentangan dengan hadis di atas dalilnya sebagai berikut:

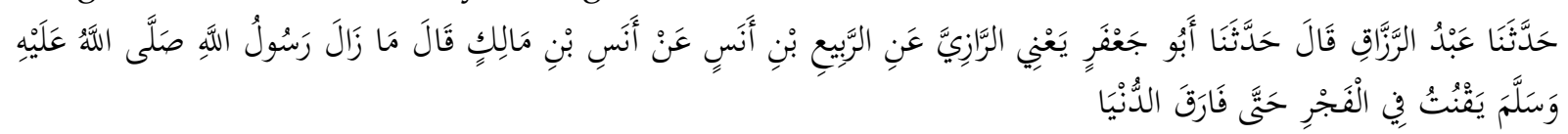
(AHMAD - 12196) : Telah menceritakan kepada kami Abdurrazaq berkata, Telah menceritakan kepada kami Abu Ja'far, yaitu ar-Razi dari ar-Rabi' bin Anas dari Anas bin

${ }^{11}$ Lidwa Pusaka i-Software - Kitab 9 Imam Hadist, Sumber : Nasa'I Kitab : Adzan Bab : Bacaan tatswib ketika adzan fajar No. Hadist : 643, http://localhost:5000/perawi_open.php?imam=nasai\&nohdt=643

${ }^{12}$ Lidwa Pusaka i-Software - Kitab 9 Imam Hadist, Sumber : Nasa'I Kitab : Pelaksanaan Bab : Tidak melakukan qunut No. Hadist : 1070, Lidwa Pusaka i-Software: www.lidwapustaka.com

13 الكتاب : صحيح وضعيف سنن النسائي المؤلف : لمُحَّمَ ناصر الدين الألباني مصدر الكتاب : برنامج منظومة التحقيقات الحديثية - الجُاني - من إنتاج مركز

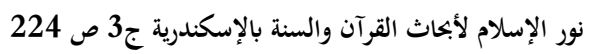


Malik berkata, "Rasulullah ShallAllohu'alaihi wa Sallam masih selalu mengerjakan qunut subuh hingga meninggal dunia."14

Demikian juga menambahi dzikir tasbih, tahmid dan takbir yang 33 kali masingmasing, sebelum zikir سبحان antara ditambah bacaan zikir, سبنان انت سبحان الله

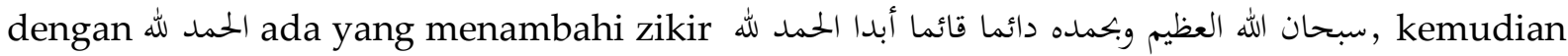

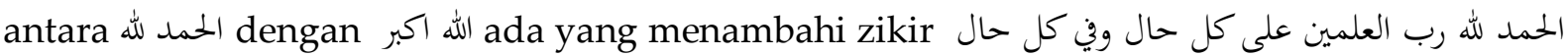
ونعمة الله اكبر

Sebaiknya adalah berdasarkan hadis yaitu:

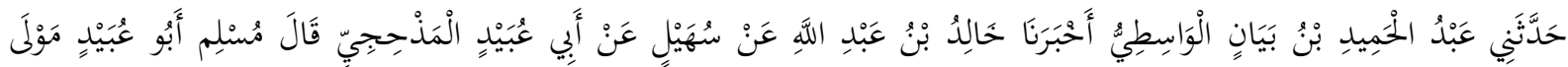

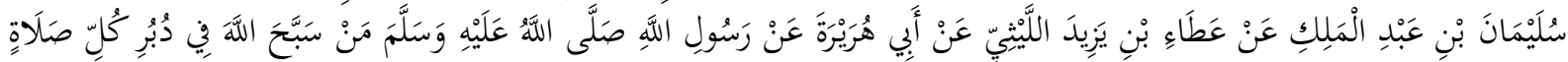

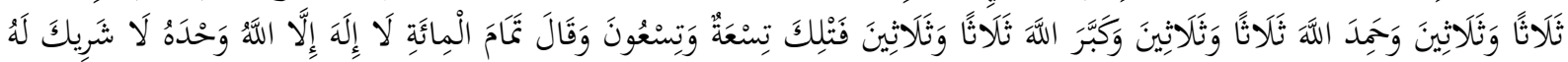

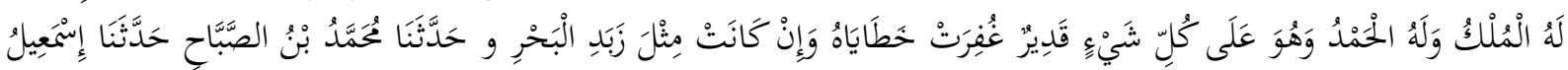

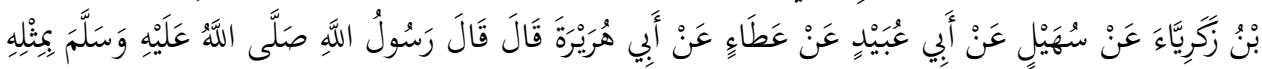
Artinya: (MUSLIM - 939) : Telah menceritakan kepadaku Abdul Hamid bin Bayan Al Wasithi telah mengabarkan kepada kami Khalid bin Abdullah dari Suhail dari Abu 'Ubaid Al Madzhiji. Muslim menjelaskan bahwa Abu Ubaid adalah mantan budak Sulaiman bin Abdul Malikdari 'Atha' bin Yazid Al Laitsi dari Abu Hurairah dari Rasulullah shallallahu 'alaihi wasallam beliau bersabda: "Barangsiapa bertasbih kepada Allah sehabis shalat sebanyak tiga puluh tiga kali, dan bertahmid kepada Allah tiga puluh tiga kali, dan bertakbir kepada Allah tiga puluh tiga kali, hingga semuanya berjumlah sembilan puluh sembilan, -dan beliau menambahkan-dan kesempurnaan seratus adalah membaca Laa ilaaha illallah wahdahu laa syariika lahu, lahul mulku walahul walahul hamdu wahuwa 'alaa kulli syai' in qadiir, maka kesalahan-kesalahannya akan diampuni walau sebanyak buih di lautan." Dan telah menceritakan kepada kami Muhammad bin Shabh telah menceritakan kepada kami Ismail bin Zakariya dari Suhail dari Abu 'Ubaid dari Atha' dari Abu Hurairah dia berkata; Rasulullah shallallahu 'alaihi wasallam bersabda seperti hadits di atas. ${ }^{15}$

Namun ada hadis dzikir tasbih, tahmid dan takbir 10 kali, dalilnya sebagai berikut:

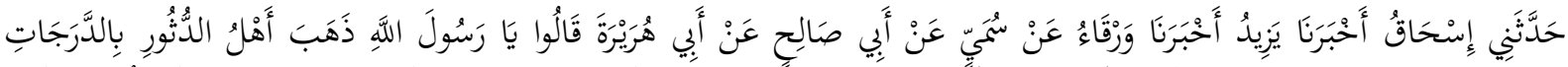

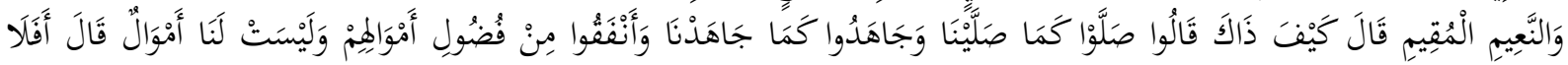

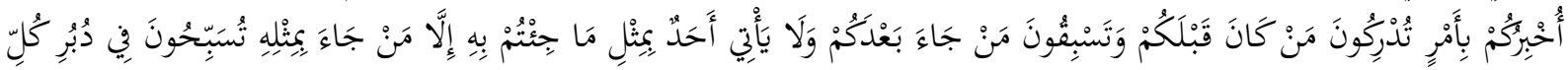

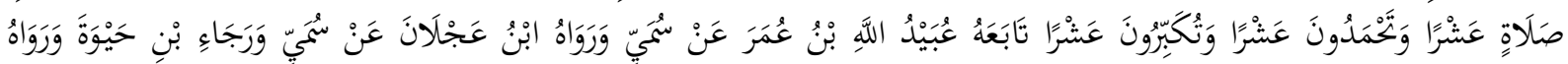

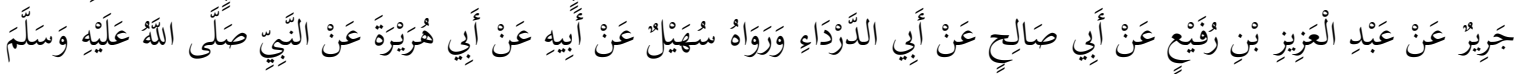
Artinya: (BUKHARI - 5854) : Telah menceritakan kepada kami Ishaq' telah mengabarkan kepada kami Yazid telah mengabarkan kepada kami Warqa' dari Sumayy dari Abu Shalih dari Abu Hurairah "Orang-orang berkata; 'Wahai Rasulullah, orang-orang kaya pergi dengan

${ }^{14}$ Lidwa Pusaka i-Software - Kitab 9 Imam Hadist, Sumber : Ahmad Kitab : Sisa Musnad sahabat yang banyak meriwayatkan hadits Bab : Musnad Anas bin Malik Radliyallahu 'anhu No. Hadist : 12196, Lidwa Pusaka i-Software: www.lidwapustaka.com

${ }^{15}$ Lidwa Pusaka i-Software - Kitab 9 Imam Hadist, Sumber : Muslim Kitab : Masjid dan tempat-tempat shalat Bab : Sunahnya dzikir setelah shalat No. Hadist : 939, http://localhost:5000/perawi_open.php?imam=muslim\&nohdt=939,www.lidwapustka.com 
membawa derajat dan kenikmatan yang banyak.' Beliau bertanya; 'Mengapa bisa seperti itu? ' Mereka menjawab; 'Mereka melakukan shalat sebagaimana kami shalat, mereka berjihad sebagaimana kami berjihad, dan mereka memiliki kelebihan harta untuk bersedekah sedangkan kami tidak mempunyai harta yang lebih untuk bersedekah.' Maka beliau bersabda: 'Maukah kalian aku tunjukkan pada suatu perkara, yang tidak akan menyamai orang sebelum kalian dan tidak pula akan di dahului oleh orang-orang setelah kalian kecuali dan tidak akan terjangkau kecuali oleh orang yang melakukan hal yang sama seperti yang kalian lakukan?' Yaitu; kalian bertasbih seusai shalat sebanyak sepuluh kali, bertahmid sebanyak sepuluh kali bertakbir sebanyak sepuluh kali.' Hadits ini juga diperkuat oleh 'Ubaidullah bin Umar dari Sumayy. Dan diriwayatkan pula oleh Ibnu 'Ajlan dari Sumayy dan Raja' bin Haiwah. Dan diriwayatkan pula oleh Jarir dari Abdul Aziz bin Rufai' dari Abu Shalih dari Abu Darda'. Dan diriwayatkan pula oleh Suhail dari Ayahnya dari Abu Hurairah dari Nabi shallallahu 'alaihi wasallam. ${ }^{16}$

Hadis ini sohih (muttfaq 'alaih) berdasarkan hasil takhrij Muhammad Nashiruddin al-Albani datanya sebagai berikut:

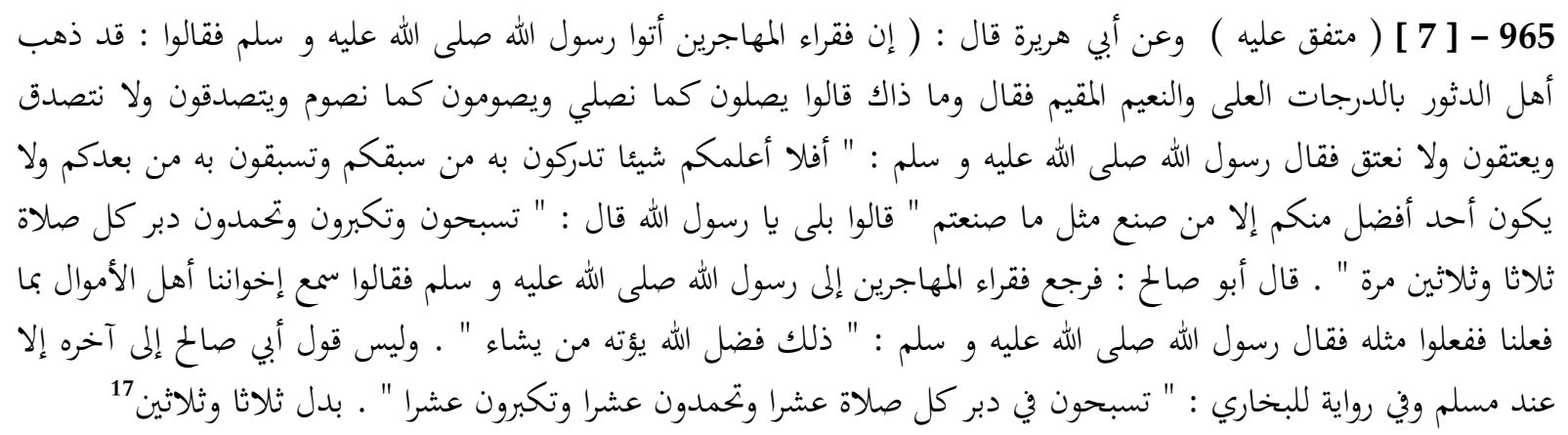
Jadi sebaiknya diikuti jumlah dan ditinggalkan tambahan yang dijelaskan di atas, kita ikuti jumlahnya maka kita diampuni dosa-dosa kita. Seharusnya wajib mengikuti jumlahnya, jika tidak apa gunanya Rosul sebutkan jumlahnya. Jika terjadi keraguan jumlah maka ikuti jumlah yang diyakini yaitu jumlah yang kecilnya maka lanjutkan kekurangannya

Perlu dipahami secara cermat dan bagus penuh perhatian sejati, saat membaca tasbih, tahmid dan takbir wajib dibaca berdasarkan ilmu tajwid dan makhroj yang baik pada akhir huruf seperti pada kata سبحان الله huruf ha-nya wajib jelas suara hurufnya diakhir, jangan karena bersambung dengan kata yang sama maka suara huruf ha-nya tidak jelas terbaca. Kemudian harus jelas berhentinya, jangan antara berhenti atau tidak. Sebaiknya pula rasakan anda sedang membaca kalimat Alloh yang indah

Demikian juga الحمد لله karena terlalu cepat suara huruf ha-nya tidak jelas, perlu jelas berhenti, dan اله أكبر, pada huruf ha yang baris dommah jika cepat membacanya akhirnya tidak jelas terbaca, maka perlu berhenti setiap kata

${ }^{16}$ Lidwa Pusaka i-Software - Kitab 9 Imam Hadist, Sumber : Bukhari Kitab : Do`a Bab : Doa setelah shalat No. Hadist : 5854, http://localhost:5000/perawi_open.php?imam=bukhari\&nohdt=5854 www.lidwapustaka.com

$$
\begin{aligned}
& \text { 17 الككتاب : مشكاة المصابيح المؤلف : مهمَّة بن عبد الله الحطيب التبريزي الناشر : المكتب الإسلامي - بيروت الطبعة : الثالثة - } 1405 \text { - } 1985 \text { تحقيق : } \\
& \text { تحقيق مُمَّمَ ناصر الدين الألباني ج1 ص } 211
\end{aligned}
$$


Dalam hal berdoa berjamaah membuat jamaah secara keseluruhan tambah bodoh terhadap menghapal doa-doa yang dijelaskan dalam Alquran dan hadis Rosul dan umat Islam tidak merasa peduli menghapal ayat Alquran dan hadis sebagai sumber doa

Umat Islam tinggal mengaminkan saja, pada gilirannya umat Islam semakin bodoh terhadap Bahasa Arab, karena jrang lidah membacanya sendiri dan menghapalnya malas

Yang paling salahnya adalah merubah redaksi ayat dan hadis yang tertulis mufrod atau tunggal maka berani menjama'kannya, contohnya:

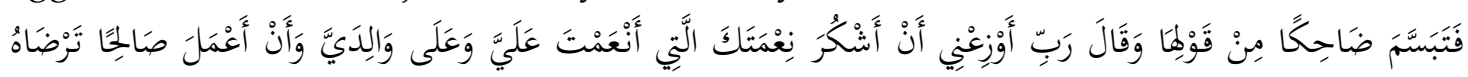

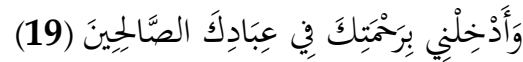

maka dia tersenyum dengan tertawa karena (mendengar) perkataan semut itu. Dan dia berdoa: "Ya Tuhanku berilah aku ilham untuk tetap mensyukuri nikmat Mu yang telah Engkau anugerahkan kepadaku dan kepada dua orang ibu bapakku dan untuk mengerjakan amal saleh yang Engkau ridhai; dan masukkanlah aku dengan rahmatMu ke dalam golongan hamba-hamba-Mu yang saleh ${ }^{18}$

maka sebahagian umat Islam doa bersama Imamnya merubah redaksinya menjadi:

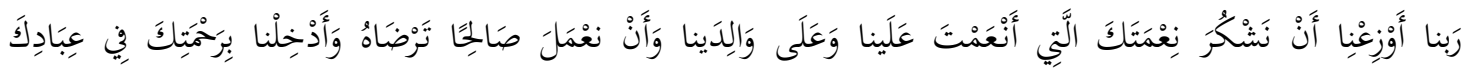

الصَّالِِينَ

3. Tetapi tidak mau merubah yang jama' dalam ayatnya atau hadisnya menjadi mufrod atau tunggal pada saat doa sendiri seperti:

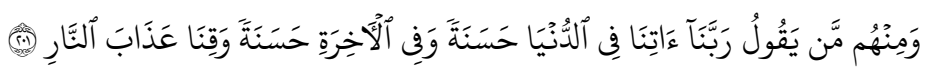

201. Dan di antara mereka ada orang yang berdoa: "Ya Tuhan kami, berilah kami kebaikan di dunia dan kebaikan di akhirat dan peliharalah kami dari siksa neraka"19 Tidak berani merubahnya menjadi mufrod atau tunggal menjadi

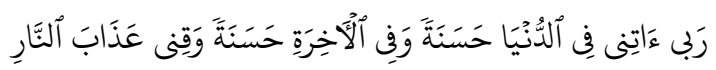

Sebaiknya wajib mengikuti redaksi yang ada,jangan karena doa bersama maka redaksi ayat dan hadis dirubah, dalilnya adalah bacaan al-Fatihah

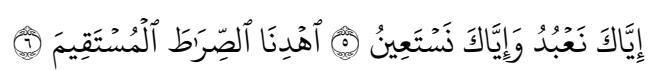

5. Hanya Engkaulah yang kami sembah, dan hanya kepada Engkaulah kami meminta pertolongan

6. Tunjukilah kami jalan yang lurus ${ }^{20}$

Bacaan نَ نَعْبَتَعِينُ didan dirubah baik solat berjamaah dan sendirian. Berdasarkan demikian maka tidak ada alasan untuk merubah redaksi ayat dan hadis, sedangkan mengurangi dan menambahi satu huruf tidak ada hak ulama, kecuali ada dalil yang murubahnya

\footnotetext{
${ }^{18}$ Q.S. an-Naml, 27:19

${ }^{19}$ Q.S.al-Baqoroh, 2:201

${ }^{20}$ Q.S al-Fatihah, 1:5-6
} 
4. Contoh hadis tidak boleh dirubah kata jama' menjadi mufrod atau tunggal, baik saat solat berjamaah atau sendirian dalilnya bacaan tasyahud awal dan akhir:

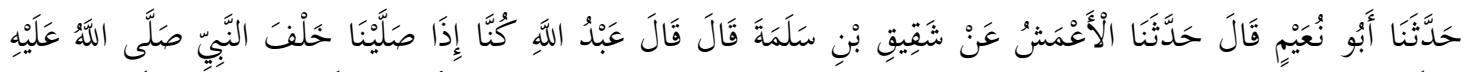

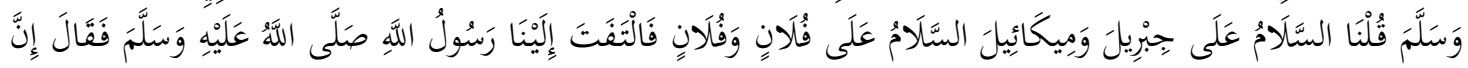

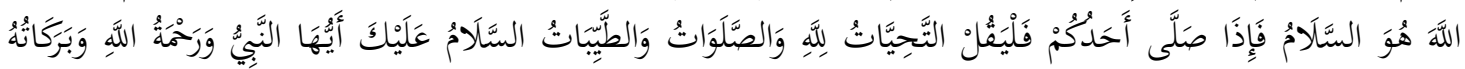

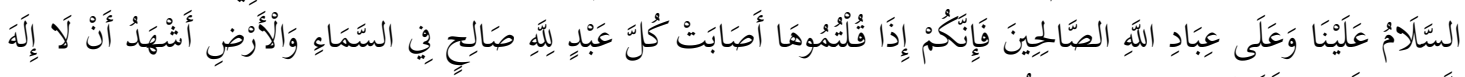

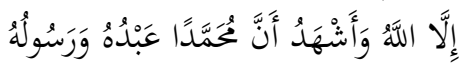

Artinya: (BUKHARI - 788) : Telah menceritakan kepada kami Abu Nu'aim berkata, telah menceritakan kepada kami Al A'masy dari Syaqiq bin Salamah berkata, berkata, " Abdullah berkata, "Jika kami shalat di belakang Nabi shallallahu 'alaihi wasallam, kami membaca: 'assalaamu 'alaa jibril wa mikaa'il. Assalaamu 'alaa fulan wa fulan (Semoga kesejahteraan terlimpahkan kepada malaikat Jibril dan Mika'il, dan semoga kesejahteraan terlimpahkan kepada si anu dan si anu) '. Lalu Rasulullah shallallahu 'alaihi wasallam menoleh ke arah kami seraya bersabda: "Sesungguhnya Allah, Dialah As-Salaam. Maka jika seseorang dari kalian shalat, hendaklah ia membaca: 'attahiyyaatu lillahi washshalawaatu waththayyibaat. Assalaamu 'alaika ayyuhannabiyyu wa rahmatullahi wa barakaatuh. Assalaamu 'alainaa wa 'alaa 'ibaadillahish shaalihiin (Segala penghormatan hanya milik Allah, juga segala pengagungan dan kebaikan. Semoga kesejahteraan terlimpahkan kepada engkau wahai Nabi dan juga rahmat dan berkah-Nya. Dan juga semoga kesejahteraan terlimpahkan kepada kami dan kepada hamba-hamba Allah yang shalih)'. Sesungguhnya jika kalian mengucapkan seperti ini, maka kalian telah mengucapkan salam kepada seluruh hamba Allah yang shalih di langit maupun di bumi. (Dan lanjutkanlah dengan bacaan): 'Asyhadu Allaa Ilaaha Illallah Wa Asyhadu Anna Muhammadan 'Abduhu Wa Rasuuluh (Aku bersaksi tidak ada tuhan yang berhak disembah selain Allah, dan aku bersaksi bahwa Muhammad adalah hamba dan utusanNya')."21

Redaksi matan yang lain sebagai berikut:

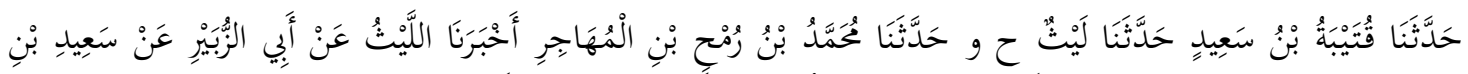

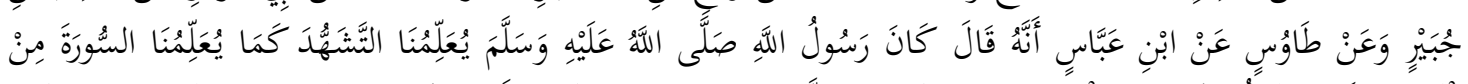

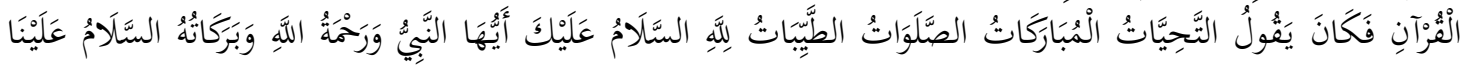

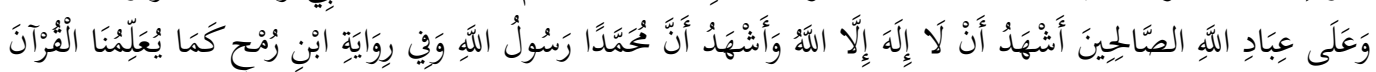
Artinya: (MUSLIM - 610) : Telah menceritakan kepada kami Qutaibah bin Sa'id telah menceritakan kepada kami Laits -lewat jalur periwayatan lain-- dan telah menceritakan kepada kami Muhammad bin Rumh bin al-Muhajir telah mengabarkan kepada kami al-Laits dari Abu az-Zubair dari Sa'id bin Jubair, dan dari Thawus dari Ibnu Abbas bahwasanya dia berkata, Rasulullah shallallahu 'alaihi wasallam mengajarkan kami tasyahhud sebagaimana beliau mengajarkan kami sebuah surat alQuran, lalu pada waktu itu beliau membaca, 'Attahiyyat ash-

${ }^{21}$ Lidwa Pusaka i-Software - Kitab 9 Imam Hadist, Sumber : Bukhari Kitab : Adzan Bab : Tasyahud Akhir

No. Hadist : 788 , http://localhost:5000/perawi_open.php?imam=bukhari\&nohdt=788 www.lidwapustaka.com 
Shalawat ath-Thayyibat Lillah, Assalamu alaika, Ayyuha an-Nabiyyu Warahmatullahi Wabarakatuhu, Assalamu'alaina wa ala Ibadillahishshaalihin. (Segala penghormatan shalawat dan juga kebaikan bagi Allah,. Semoga keselamatan terlimpahkan kepadamu wahai Nabi dan juga rahmat dan berkahnya. Semoga keselamatan terlimpahkan atas kami dan hamba Allah yang shalih. Saya bersaksi bahwa tidak ada tuhan (yang berhak disembah) melainkan Allah, dan saya bersaksi bahwa Muhammad adalah utusan Allah) '. Dan dalam suatu riwayat, "Sebagaimana beliau mengajarkan kepada kami al-Qur'an."22

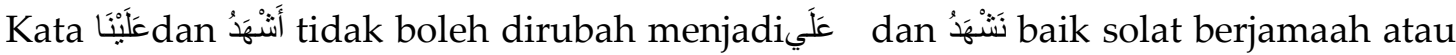
sendirian, demikian pentingnya mengikuti sunnah

5. Dan perlu lagi kita perhatikan dari dua matan tentang bacaan tsyahud di atas, tidak diastukan bacaan tasyahud dengan bacaan solawat kepada Nabi, menunjukkan bacaan tasyahud tidak boleh ditambahi saat tasyahud awal

6. Bacaan tasyahud awal dilanjutkan dengan doa berikut dalilnya:

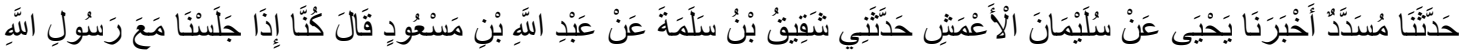

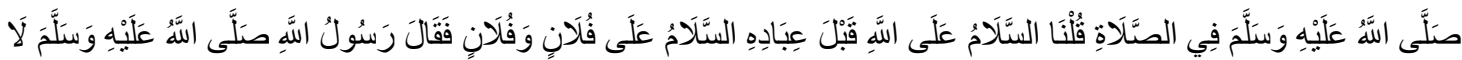

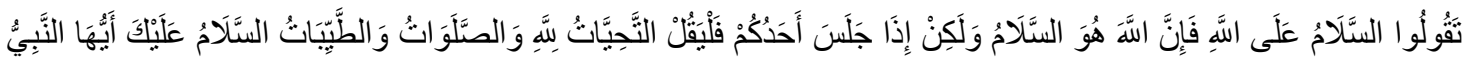

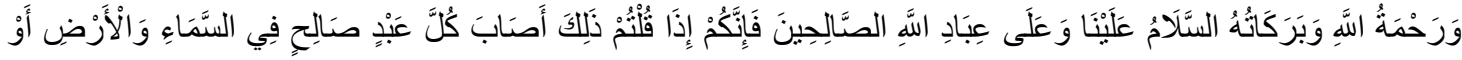

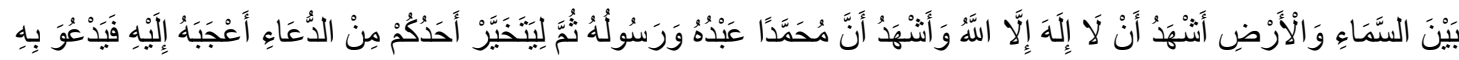

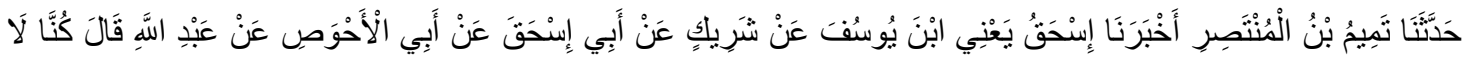

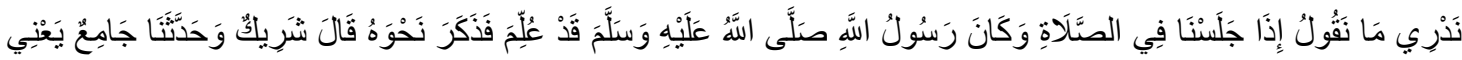

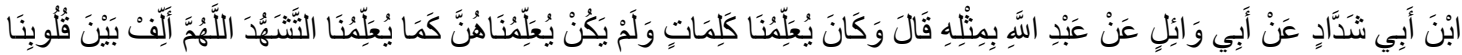

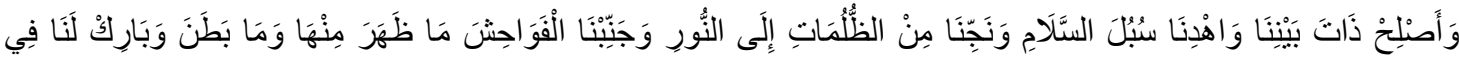

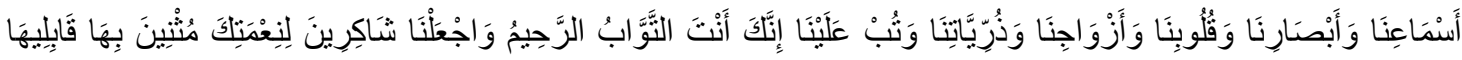

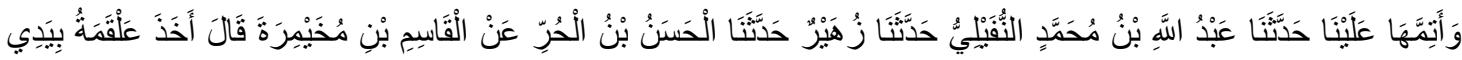

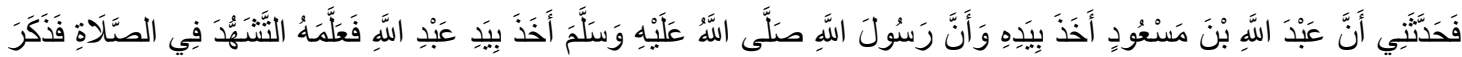

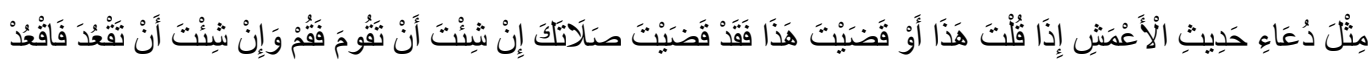
(ABUDAUD - 825) : Telah menceritakan kepada kami Musaddad telah mengabarkan kepada kami Yahya dari Sulaiman Al A'masy telah menceritakan kepadaku Syaqiq bin Salamah dari Abdullah bin Mas'ud dia berkata; "Apabila kami selesai dudukduduk bersama bersama Rasulullah shallallahu 'alaihi wasallam dalam shalat, maka kami ucapkan; "As Salaamu 'alallah qabla 'ibaadihis salaam'ala fulaanin wa fulaan (selamat sejahtera bagi Allah sebelum hamba-bamba-Nya, selamat sejahtera bagi fulan dan fulan)." Maka Rasulullah shallallahu 'alaihi wasallam bersabda: "Janganlah kalian mengatakan "As Salaamu 'alaallah, karena Allah adalah dzat sumber keselamatan, akan tetapi jika salah seorang dari kalian duduk hendaklah

${ }^{22}$ Lidwa Pusaka i-Software - Kitab 9 Imam Hadist, Sumber : Muslim Kitab : Shalat Bab : Tasyahud No. Hadist : 610, http://localhost:5000/perawi_open.php?imam=muslim\&nohdt=610 
mengucapkan; 'At Tahiyyati lillah was shalawaatu wat thayyibaat, as salaamu 'alaika ayyuhan nabiiyyu warahmatullahi wa barakaatuh as salaamu 'alaina wa 'alaa ibaadillahis shalihin (Segala kesejahteraan milik Allah semata, begitupun segala kasih-sayang dan hal-hal yang baik, selamat sejahtera kiranya terlimpah kepadamu wahai Nabi, begitupun rahmat Allah serta berkah-berkah-nya. Selamat sejahtera terlimpah pula atas kami dan atas hamba-hamba Allah yang Shalih) " apabila kalian mengucapkan seperti ini, maka kalian dapat mencapai semua hamba yang Shalih baik yang di langit maupun yang di bumi, -atau sabdanya- di antara langit dan bumi. ' "Asyhadu allaa ilaaha illallah wa asyhadu ann namuhammadan 'abduhu wa rasuuluh (Aku bersaksi bahwa tidak ada ilah selaian Allah, dan aku bersaksi bahwa Muhammad itu adalah hamba dan utusan-Nya) ", kemudian hendaklah salah seorang dari kalian memilih do'a yang menarik hatinya dan berdo'a dengan do'a itu." Telah menceritakan kepada kami Tamim bin Al Muntashir telah mengabarkan kepada kami Ishaq yaitu Ibnu Yusuf dari Syarik dari Abu Ishaq dari Abu Al Ahwash dari Abdullah dia berkata; "Kami tidak tahu, apa yang harus kami baca ketika duduk dalam shalat, sedangkan Rasulullah shallallahu 'alaihi wasallam telah di ajari (oleh Allah) ..." kemudian dia menyebutkan hadits yang semisal itu." Syarik mengatakan; dan telah menceritakan kepada kami Jami' yaitu ibnu Abu Syaddad dari Abu Wa'il dari Abdullah seperti itu, katanya; "Dan beliau telah mengajari kami beberapa kalimat, dan tidak mengajari kami kalimat-kalimat di atas sebagaimana beliau mengajari kami tasyahud, (sabdanya): "Allahumma allif baina quluubina wa ashlih dzaata bainina wahdinaa subulus salaam wa najjinaa minad dlulumaati ilan nuur wa jannibnal fawaahisy maa dlahara minhaa wa maa bathana wa baarik lanaa fii asmaa'ina wa abshaarinaa wa quluubinaa wa azwaajinaa wa dzurriyyatinaa wa tub 'alainaa innaka anta tawwaabur rahim, wa ja'alna syaakiriin, lini'matika mutsniin bihaa qaabiliha wa atimmaha alainaa (Ya Allah, jinakkanlah antara hati kami, perbaikilah hubungan di antara kami, tunjukilah kami jalan yang lurus, selamatkanlah kami dari kegelapan menuju cahaya, hindarkanlah kami dari perbuatan keji baik yang nampak maupun yang tersembunyi, berkahilah kami pada pendengaran kami, penglihatan kami, hati kami, isteri-isteri kami dan anak cucu kami, terimalah taubat kami karena Engkau adalah dzat yang Maha penerima taubat dan Maha penyayang, jadikanlah kami dalam kelompok yang pandai bersyukur, terhadap nikmat-nikmat-Mu kami bersyukur, terimalah dan sempurnakanlah atas kami." Telah menceritakan kepada kami Abdullah bin Muhammad An Nufaili telah menceritakan kepada kami Zuhair telah menceritakan kepada kami Al Hasan bin Al Hurr dari Al Qasim bin Mukhaimirah dia berkata; 'Alqamah memegang tanganku, lalu menceritakan kepadaku bahwa Abdullah bin Mas'ud pernah memegang tangannya, dan Rasulullah shallallahu 'alaihi wasallam juga pernah memegang 
tangan Abdullah bin Mas'ud, lalu beliau mengajarinya tasyahud dalam shalat..." kemudian dia menyebutkan seperti do'a dalam haditsnya Al A'masy, (sabdanya): "Apabila kamu telah mengucapkan do'a tersebut atau memenuhi do'a ini, maka kamu benar-benar telah memenuhi shalatmu, jika kamu hendak berdiri, berdirilah dan jika hendak duduk, maka duduklah."23

Maksudnya jika berdiri bagi yang sanggup berdiri untuk rokaat ketiga, dan duduk bagi yang tidak mampu berdiri karena sakit atau tua

7. Solawat kepada Nabi hanya pada tasyahud akhir

8. Demikian juga menambahi bacaan solawat kepada Nabi dengan kata

9. Karena Nabi Muhammad tidak suka diberi gelar atau nama diluar yang diberi Alloh subhanahu wa ta'ala dalilnya sebagai berikut:

Empat enam

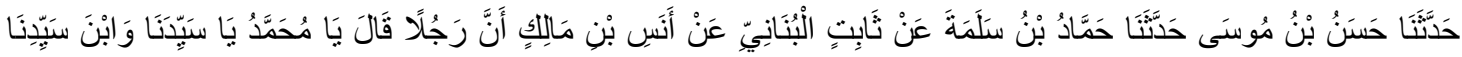

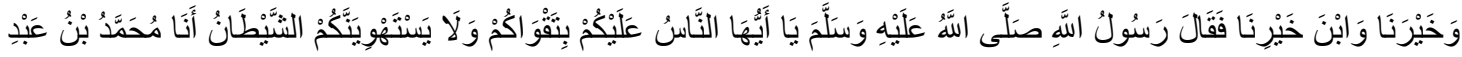

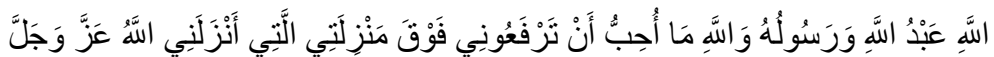

Artinya: (AHMAD - 12093) : Telah menceritakan kepada kami Hasan bin Musa telah menceritakan kepada kami Hammad bin Salamah dari Tsabit al-Bunani dari Anas bin Malik, ada seorang laki laki yang bertanya: "Wahai Muhammad, wahai tuan kami dan anaknya tuan kami, dan sebaik-baik dari kami dan anak dari sebaik-baik kami", maka Rasulullah Shallallahu'alaihi wa Sallam bersabda: "Wahai manusia, bertakwalah kalian kepada Allah, dan janganlah kalian tertipu tipu daya setan, saya Muhammad bin Abdullah, hamba Allah dan Rasul-Nya. Demi Allah, saya tidak senang kalian mengangkat diriku lebih diatas derajat yang telah Allah 'azza wajalla berikan kepadaku."24

Hadis ini kualitas sanadnya sohih berdasarkan hasil takhrij Muhammad Nashiruddin al-Albani datanya sebagai berikut:

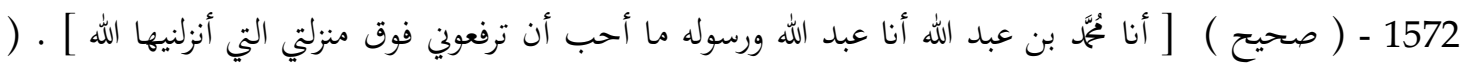

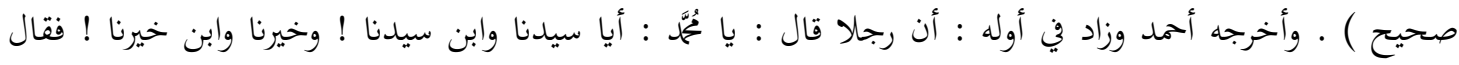

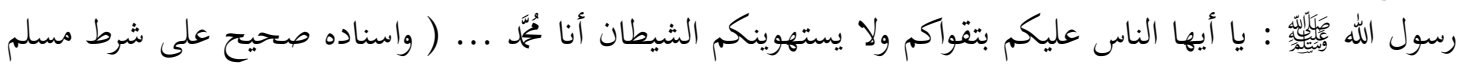

10. Menambahi bacaan بـ setiap memulai suroh atau ayat sesudah membaca al-Fatihah pada rokaat pertama dan kedua pada solat fardu dan setiap rokaat pada solat sunnah

${ }^{23}$ Lidwa Pusaka i-Software - Kitab 9 Imam Hadist, Sumber : Abu Daud Kitab : Shalat Bab : Tasyahud No. Hadist : 825 , http://localhost:5000/perawi_open.php?imam=abudaud\&nohdt=825 www.lidwapustka.com

${ }^{24}$ Lidwa Pusaka i-Software - Kitab 9 Imam Hadist, Sumber : Ahmad Kitab : Sisa Musnad sahabat yang banyak meriwayatkan hadits Bab : Musnad Anas bin Malik Radliyallahu 'anhu No. Hadist : 12093, http://localhost:5000/perawi_open.php?imam=ahmad\&nohdt=12093,www.lidwapustka.com

[25 السلسلة الصحيحة - الألباني ] الكتاب : السلسلة الصحيحة المؤلف : محمَّ ناصر الدين الألباني الناشر : مكتبة المعارف - الرياض ج 4 ص 101 
11. Analisisnya apa perbedaan satu ركوع disingkat dengan huruf 2 maksudnya setiap sampai bacaan kita saat solat maka diperbolehkan untuk ruku', sekaligus merupakan indikator atau ukuran solat yang ringan jika kita berjamaah

12. Buktinya ayat solat ringan adalah solat jumua'h ayatnya rokaat pertama suroh Jumu'ah terdiri dari ركوع namun dibuat satu rokaat dan rokaat kedua suroh alMunafiqun juga 2 ركوع dijadikan satu rokaat pada rokaat kedua

13. Yang diperintahkan adalah membaca isti'adzah setiap memulai membaca ayat Alquran baik di awal suroh atau ditengah suroh dengan sir atau berbisik. Dalilnya sebagai berikut:

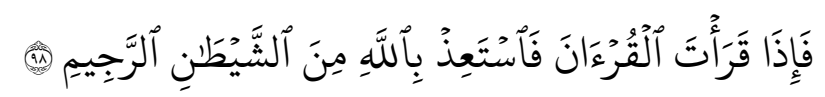

Artinya: Apabila kamu membaca Al Quran hendaklah kamu meminta perlindungan kepada Allah dari syaitan yang terkutuk ${ }^{26}$

14. Demikian juga membaca qunut witir yang ditambahi umat atau mereka rubah dengan menjama'kan, mengangkat tangan, mengaminkannya oleh makmum setiap nafas berhenti Iamam, menjaharkannya qunut separohnyadan mensirrkan lainnya

15. Sebahagian umat Islam mengamalkan tidak ada solat sunnah ba'da jika diselingi solat janazah

16. Namun ditanya mana dalilnya dia menjwab tidak ada solat sunnah sesudah solat janazah, yang ada setelah solat fardu yang ada dalil solat sunnah ba'danya

17. Tetapi setelah dilakukan penjejakan hadis yang melarangnya belum ditemukan, karena solat janazah bukan solat fardu rutin yang ditentukan waktunya

18. Jadi tidak mungkin solat yang tidak tertentu waktunya memansukhkan solat sunnah yang mengikutinya atau rowatibnya

19. Sebenarnya boleh menmahi bacaan atau mengurangi bacaan dan jumlah rokaat jika ada dalilnya seperti mengurangi jumlah rokaat zuhur dan asar menjadi 2 rokaat saat musafir atau qosor jama', menjadi 1 rokaat saat khouf (an-Nisa' ayat 102) . Ayat ini diperjelas dengan hadis Rosul sebagai berikut:

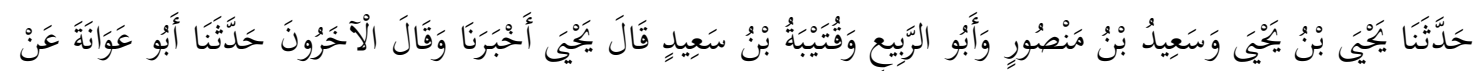

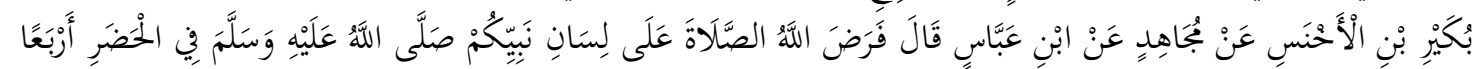

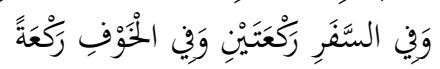

Artinya: (MUSLIM - 1109) : Telah menceritakan kepada kami Yahya bin Yahya dan Sa'id bin Manshur dan Abu Rabi' dan Qutaibah bin Sa'id. Yahya mengatakan; telah mengabarkan kepada kami, sedangkan yang lainnya mengatakan; telah menceritakan kepada kami Abu 'Awanah dari Bukair bin Al Akhnas dari Mujahid dari Ibnu Abbas, katanya; "Allah mewajibkan shalat melalui lisan Nabi shallallahu 'alaihi wasallam kalian, ketika mukim sebanyak empat raka'at, dan

${ }^{26}$ Q.S. an-Nahl, 16:98 
ketika safar sebanyak dua raka'at dan ketika kondisi ketakutan sebanyak satu rakaat."27

Hadis ini kualitas sanadnya adalah mutafaq alaih berdasarkan hasil takhrij Muhammad Nashiruddin al-Albani datanya seagai berikut:

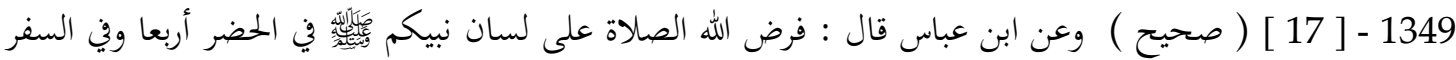

ركعتين وفي الخوف ركعة . رواه مسلم 28

20. Ukuran ayat yang dibaca saat solat minimalnya 1 ruku', jika solat sendirian semau kita dalilnya:

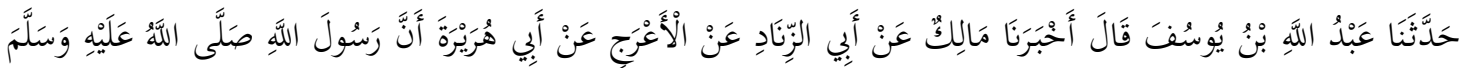

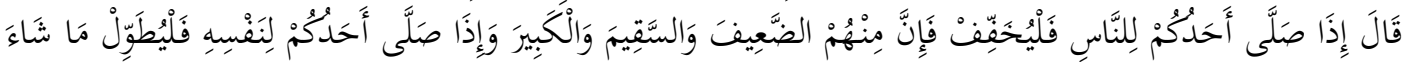

Artinya: (BUKHARI - 662) : Telah menceritakan kepada kami 'Abdullah bin Yusuf berkata, telah mengabarkan kepada kami Malik dari Abu Az Zinad dari Al A'raj dari Abu Hurairah bahwa Rasulullah shallallahu 'alaihi wasallam bersabda: "Jika seseorang dari kalian memimpin shalat orang banyak, hendaklah dia meringankannya. Karena di antara mereka ada orang yang lemah, orang yang sakit dan orang berusia lanjut.

Namun bila dia shalat sendiri silahkan dia panjangkan sesukanya."29

Hadis ini kualitas sanadnya adalah mutafaq alaih berdasarkan hasil takhrij Muhammad Nashiruddin al-Albani datanya seagai berikut:

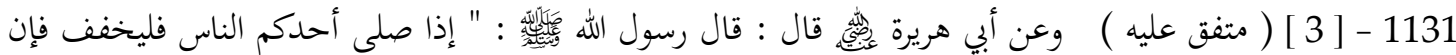

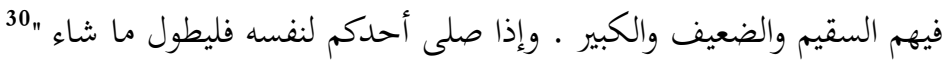

\section{PENUTUP}

1. Tastwib adalah bacaan الصلاة خير من النوم bid'ah membacanya pada adzan solat Zuhur dan 'Asar,tentu demikian pada solat Magrib dan Isya' dan solat subuh pada adzan kedua,

2. Pada adzan pertama sebelum masuk waktu subuh disepakati satu jam sebelum masuk waktu subuh.

3. Analisisnya terhadap ibadah lain adalah menambahi atau mengurangi bacaan yang sudah ada dalam Alquran dan hadis

4. Menambahi tasbih, tahmid dan takbir dari $33 \mathrm{kali}$, demikian juga nenambahi bacaan sebelum membaca tasbih, antara tasbih dengan tahmid, antara tahmid dengan takbir.

5. Menambahi bacaan tasyahud awal dengan solawat kepada Nabi

${ }^{27}$ Lidwa Pusaka i-Software - Kitab 9 Imam Hadist, Sumber : Muslim Kitab : Shalatnya musafir dan penjelasan tentang qashar Bab : Mengqadla shalat yang tertinggal dan sunahnya bersegera dalam mengqadlanya No. Hadist : 1109, http://localhost:5000/perawi_open.php?imam=muslim\&nohdt=1109

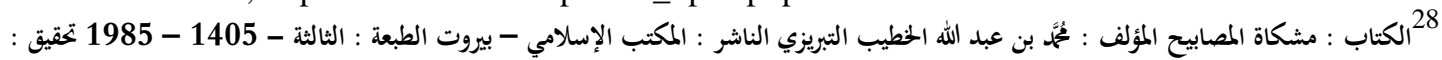

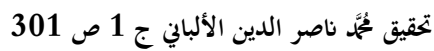

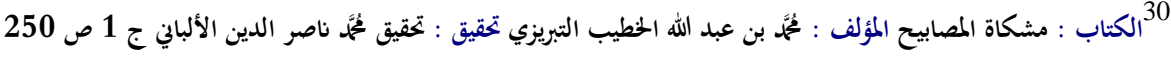


6. solawatnyapun hanya diawal saja tidak sempurna sesuai dengan solawat berdasarkan hadis Rosul

7. Kemudian juga menambahi kata سيدنا pada bacaan solawat

8. Dalam berdoa berjamaah, dirobahlah ayat atau hadis dari yang mufrod atau tunggal menjadi jama' karena kondisi doa bersama

9. Namun sebaliknya tidak berani merubah ayat atau hadis yang jama' semjla merubahnya menjadi mufrod atau tunggal saat doa sendirian.

10. Sebaiknya jangan robah redaksi ayat atau hadis maka berdoalah dengan masingmasing berbisik agar tidak mengganggu orang lain seperti dalam solat

\section{DAFTAR PUSTAKA}

\section{Alquranul Karim}

Lidwa Pusaka i-Software - Kitab 9 Imam Hadist al-Bukhori

Lidwa Pusaka i-Software - Kitab 9 Imam Hadist Muslim

Lidwa Pusaka i-Software - Kitab 9 Imam Hadist Abu Dawud

Lidwa Pusaka i-Software - Kitab 9 Imam Hadist at-Tirmidzi

Lidwa Pusaka i-Software - Kitab 9 Imam Hadist an-Nasai

Lidwa Pusaka i-Software - Kitab 9 Imam Hadist Ibn Majah

Lidwa Pusaka i-Software - Kitab 9 Imam Hadist Musnad Ahmad

Lidwa Pusaka i-Software - Kitab 9 Imam Hadist Malik Muwattho'

Lidwa Pusaka i-Software - Kitab 9 Imam Hadist Sunan ad-Darimi

$$
\begin{aligned}
& \text { لكتاب : إرواء الغليل في تخريج أحاديث منار السبيل المؤلف : كُمَّمَ ناصر الدين الألباني الناشر : المكتب الإسلامي - بيروت الطبعة : الثانية - } 1405
\end{aligned}
$$

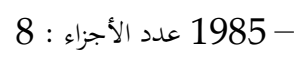

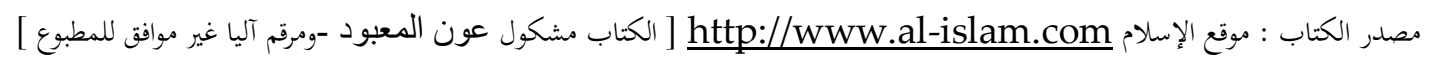

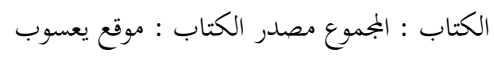

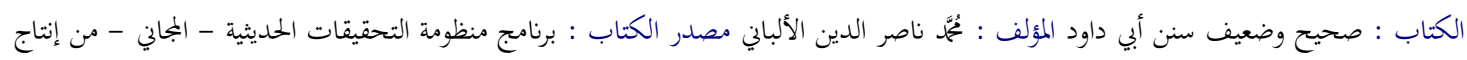

$$
\begin{aligned}
& \text { مركز نور الإسلام لأبحاث القرآن والسنة بالإسكندرية }
\end{aligned}
$$

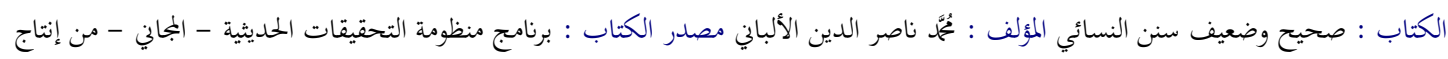

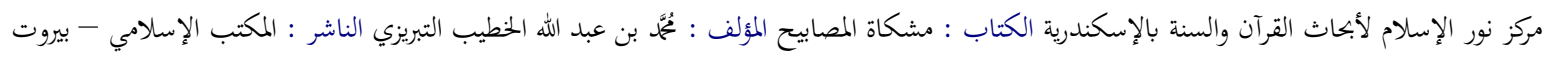

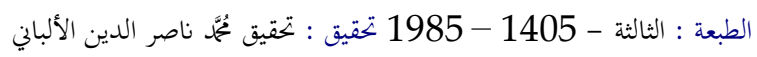

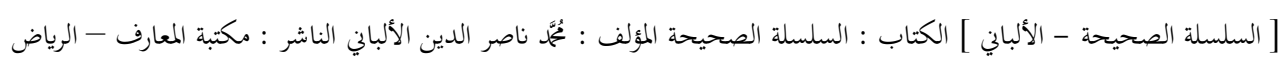

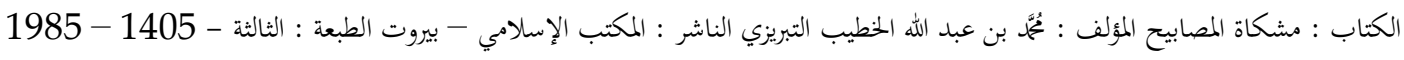

$$
\begin{aligned}
& \text { تحقيق : تحقيق مُحَّم ناصر الدين الألباني }
\end{aligned}
$$

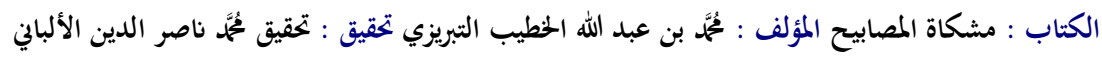

